\title{
Appropriate Smart Factory : Demonstration of Applicability to Industrial Safety
}

\author{
Kui-Kam Kwon', Woo-Kyun Jeong², Hyungjung Kim¹, Ying-Jun Quan', Younggyun Kim³ \\ Hyunsu Lee ${ }^{3}$, Suyoung Park ${ }^{3}$, Sae-Jin Park ${ }^{3}$, SungJin Hong ${ }^{3}$, Won-Jae Yun ${ }^{3}$, Guyeop Jung ${ }^{3}$, \\ Gyu Wha Lee ${ }^{3}$, Sung-Hoon Ahn ${ }^{3, \dagger}$ \\ ${ }^{1}$ Institute of Advanced Machines and Design, Seoul National University, Seoul 08826, Republic of Korea \\ ${ }^{2}$ Soft Robotics Research Center, Seoul National University, Seoul 08826, Republic of Korea \\ ${ }^{3}$ Department of Mechanical Engineering, Seoul National University, Seoul 08826, Republic of Korea
}

\section{적정 스마트공장: 산업안전 기술로의 적용 가능성 실증}

\author{
권귀감 ${ }^{1}$, 정우균 ${ }^{2}$, 김형중 ${ }^{1}$, 전영준 ${ }^{1}$, 김영균 $^{3}$, 이현수 $^{3}$, 박수영 $^{3}$, 박세진 ${ }^{3}$, \\ 홍성진 ${ }^{3}$, 윤원재 ${ }^{3}$, 정구엽 ${ }^{3}$, 이규화 $^{3}$, 안성훈 ${ }^{3, \dagger}$ \\ 1정밀기계설계공동연구소, 서울대학교, 서울 08826 , 대한민국 \\ ${ }^{2}$ 인간중심소프트로봇기술연구센터, 서울대학교, 서울 08826 , 대한민국 \\ ${ }^{3}$ 기계공학부, 서울대학교, 서울 08826 , 대한민국
}

\begin{abstract}
산업안전에 대한 관심이 증가하는 가운데 최근 제조현장에서 다양한 방법으로 적용되고 있는 스마트공장 기술을 활용 한 산업재해 방지 기술도 다양하게 연구되고 있다. 하지만 현실적인 문제로 인해 산업재해의 큰 비중을 차지하는 중 소기업에서 이러한 스마트공장 기술의 적용을 통한 산업재해 방지에 어려움이 따르고 있다. 본 연구에서는 산업재해 유형별 맞춤형 모니터링 및 경보 시스템을 개발하고 실제 현장에 적용하였으며, 이를 통해 중소기업에서 활용할 수 있 는 적정 스마트공장 기술을 통한 산업재해 방지 기술을 실증하였다. 작업자 신체 접근, 누전 및 과전류, 고온에 의한 화재 및 화상, 유해물질 배출이라는 네 가지 주요 재해 유형에 대해 비전센서, 전류센서, 온도센서 및 가스센서를 활 용하여 맞춤형 모니터링 시스템을 구축하였다. 더불어 모니터링 된 위험요소 빠르게 인지할 수 있도록 작업환경에 맞 는 알림 방안을 적용하고, 실시간 데이터 전송 및 디스플레이를 활용하여 작업자와 관리자가 재해 위험을 효과적으로 인지할 수 있도록 하였다. 이러한 적정 스마트공장 기술의 적용 및 실증을 통한 효과를 확인하고 이러한 산업안전 기 술의 확산에 대해 논의하고자 한다.
\end{abstract}

As industrial safety increases, various industrial accident prevention technologies using smart factory technology are being studied. However, small and medium enterprises (SMEs), which account for the majority of industrial accidents, are having difficulties in preventing industrial accidents by applying these smart factory technologies due to practical problems. In this study, customized monitoring and warning systems for each type of industrial accident were developed and applied to the actual field. Through this, we demonstrated industrial accident prevention technology through appropriate smart factory technology used by SMEs. A customized monitoring system using vision, current, temperature, and gas sensors was established for the four major disaster types: worker body access, short circuit and overcurrent, fire and burns due to high temperature, and emission of hazardous gas. In addition, a notification method suitable for each work environment was applied so that the monitored risk factors could be recognized quickly, and real-time data transmission and display enabled workers and managers to understand the disaster risk effectively. Through the application and demonstration of these appropriate smart factory technologies, the spread of these industrial safety technologies is to be discussed.

\footnotetext{
†To whom correspondence should be addressed.

E-mail: ahnsh@snu.ac.kr

Received: 8 October 2021, Revised: 3 November 2021,

Accepted: 3 November 2021
}

KEYWORDS: Appropriate smart factory, Safety monitoring system, Small and medium enterprises (SME), Monitoring system, Hazard notification 
서론

근래에 제조기술의 발전은 센서, 연산장치, 데이터 처리 기술 등의 발전에 힘입어 나날히 스마트화 되어가고 있다. 제조기술의 스마트화 연구 개발은 학계와 산업계 전반에 걸 쳐 진행되고 있으며 그 범위 또한 단위공정에서부터 전체 공정 시스템 관리에 이르기까지 다양한 영역에서 이루어지 고 있다. 스마트공장 기술은 다양한 센서를 제조 장비에 설 치하여 대량의 데이터를 수집 및 실시간 처리하여 제품의 품질과 생산성 향상을 꾀하는 방향으로 주되게 연구되고 있 다. 이러한 제조기술 발전에도 불구하고 대한민국 제조업에 서의 산업재해는 전체 산업 대비 높은 비중을 차지하고 있 으며 그 수에 큰 변화없이 지속적으로 발생하고 있어 산업 재해에 대한 예방과 대응에 대한 연구가 필요하다(산업통 상자원부, 2020). 특히 ‘중대재해처벌법'의 시행으로 인명피 해에 따른 기업의 책임이 증가하지만 이에 대한 대응책 마 련에는 많은 중소기업들이 어려움을 표하고 있어 중소기업 에서도 효과적으로 인명피해를 막을 수 있는 방안 마련이 시급한 실정이다(오병선, 2021; 중소기업중앙회, 2021).

기존에 주되게 연구되고 적용되고 있는 스마트공장 기술 의 경우 다양한 센서에서 수집된 데이터를 활용해 생산성 이나 품질 향상, 생산시스템 변화를 꾀하고 있으나 이러한 개발 방향의 경우 앞서 언급한 제조업에서의 높은 산업재 해 발생률을 해결하고 실질적인 기업 안전을 발전시키는 데 에 한계점이 존재한다. $\mathrm{AI}($ Artificial Intellitence), IoT (Internet of Things) 와 같은 스마트공장 기술을 활용하여 작업성능 을 향상시키는 연구들의 경우 안전관련 이슈들에 대해 고 려하지 않고 진행하여 위험이 발생할 여지가 있다. 이러한 문제를 해결하고 작업환경 안전을 향상하기 위해 스마트공 장 기술을 적용시키고자 하는 시도가 지속적으로 나타나고 있다(Jung et al., 2021; Cheng et al., 2021; Jeong and Cho, 2019). 작업자 안전을 해결하고자 하는 워크플로우 구축 (Afrin et al., 2019), 이미지 기반 물체 인식(Buerkle et al., 2021), 로봇과의 충돌방지(Lee et al., 2021) 등 AI기술을 기 반으로 산업재해를 방지하고자 하는 연구가 다방면으로 진 행되고 있으나 이러한 연구들은 생산성 및 품질에 대한 연 구에 비해 그 수가 적고, 연구실 수준에서 진행하는 경우가 많아 실제 산업현장에서 적용이 어려운 실정이다. 더불어 다 양한 제조업체에서 스마트공장 기술은 제한적으로 적용되 고 있으며, 중소기업의 경우 ‘투자자금 부담', ‘전문 인력 확 보 어려움' 등의 문제로 이러한 스마트공장 기술을 적용하 는 데에 어려움이 있다(중소기업기술정보진흥원, 2017). 이 는 실질적인 산업재해 저감에 있어 큰 걸림돌이 되는데 전 체 산업재해 중 대부분이 50 인 미만의 소형 사업장에서 발
생하고 있기 때문이다.

본 연구에서는 이러한 문제를 해결하고자 중소기업 작업 자 개인과 공장 전체의 위험을 감지하고 이를 알릴 수 있 는 맞춤형 적정 안전 스마트공장 기술을 제안하고, 이를 실 제 중소기업에 적용 및 실증하였다. 중소기업에서 주되게 발 생할 수 있는 산업재해 유형을 선정하고 각각의 위험을 감 지할 수 있는 센서와 작업자와 관리자에게 효과적으로 이 를 알릴 수 있는 시청각적 알림장치 및 데이터 관리 시스 템을 제작하였다. 개발된 센서 플랫폼은 실제 경기도 시화 공단의 공장에 설치하여 실제 산업 현장에서 위험 감지 및 작업자 위험 알림에 의한 작업환경 안전성 향상을 실증하 였다.

\section{적정 안전 스마트공장 기술의 개념}

기존의 고도의 기술과 자본을 필요로 하는 스마트공장 기 술을 중소기업 적용할 수 있도록 하는 적정 스마트공장에 대한 논의가 최근 지속적으로 진행되었으며(안성훈, 2018; 장현주, 2018), 이러한 적정 스마트공장의 개념은 기존 연 구를 통해 정립된 바 있다(Jeong and Cho, 2019). 앞서 언급 된 바와 같이 중소기업의 경우 투자자금과 전문인력 부족 으로 인해 스마트공장 적용에 어려움이 있으며, 이를 해결 하기 위해 즉각적으로 활용 가능하면서도 유지비용이나 전 문가가 필요하지 않은 기술이 필요하다. 적정 스마트공장은 기업/공정별 맞춤형 스마트 기술을 적용하여 저비용으로 현 장에서 운용이 가능한 기술로써, ‘적정 기능(Essential)', ‘구매 가능(Affordable)', ‘적용 용이성(Simple)', ‘장비 호환성 (Interoperable)'의 네 가지 요소로 구성된다. 여기서 각각의 요소들은 다음과 같이 설명될 수 있다. '적정 기능'은 특정 제품 생산에 반드시 필요한 기술을 적용하는 것으로, 추가 적인 기술이나 장비의 설치를 방지하여 기술 적용의 부담 을 최소화하는 방향을 뜻하며, '구매 가능'은 중소기업에서 부담할 수 있는 적절한 수준의 비용을 의미한다. '적용 용 이성'은 작업자와 관리자가 해당 기술을 쉽게 작동 및 유지 보수할 수 있는 특성으로 이를 통해 전문가 활용에 대한 부 담을 줄일 수 있다. 마지막으로 ‘장비 호환성'을 통해 단일 장비뿐 아니라 공장의 다양한 장비에 같은 기술을 적용할 수 있게 한다.

적정 스마트공장의 적용을 통해 다양한 스마트공장 기술 을 중소기업에 적용할 수 있으며, 이는 소형 사업장에서 주 되게 발생하는 안전사고 방지에 있어서 효과적인 해결책이 될 수 있다. 이러한 스마트공장 기술을 안전사고 방지에 활 용하는 적정 안전 스마트공장 기술을 통해 사고 위험이 높 은 장비나 공정에 맞춤형 스마트공장 기술을 적용하여 사 
Table 1. 제조현장 주위험유형 및 설비별 적용 가능한 센서 기술

\begin{tabular}{|c|c|c|c|}
\hline 위험유형 & 위험설비 & 재해위험 감지 방안 & 적용 센서 \\
\hline 장비끼임 & 프레스 머신 & \multirow{2}{*}{ 위험구역 변화 감지 } & \multirow{2}{*}{ 비전 센서 } \\
\hline 절단·베임·찔림 & 드릴링/탭핑 머신 & & \\
\hline 누전 & 전 설비 & 이상전류 / 과전류 감지 & 전류 센서 \\
\hline 화재 & \multirow{2}{*}{ 용해로, 열처리로 } & \multirow{2}{*}{ 이상 고온 감지 } & \multirow{2}{*}{ 온도 센서 } \\
\hline 화상 & & & \\
\hline 화학물질 누출 & 용접장비, 용해로 & 위해 물질 감지 & 환경감지 센서 \\
\hline
\end{tabular}

고를 사전에 경고하거나 방지할 수 있다. 특히 안전장비가 설치되어 있지 않은 구형 장비나 수작업을 필요로 하는 저 가형 장비에 데이터 취득, 처리 및 경고가 가능한 장비/공 정 맞춤형 센서 플랫폼을 설치함으로써 기존에 작업자가 즉 각적으로 알 수 없었던 위험요소를 경고하고 안전재해를 효 과적으로 방지할 수 있을 것으로 예상된다.

\section{적정 안전 스마트공장 기술 개발 및 실증 방안}

\section{1. 주요 문제점 선정}

적정 스마트공장 기술의 개발을 위해 산업재해 위험 측 정 플랫폼을 통합적으로 구축하는 것이 아니라 업체별로 발 생할 수 있는 산업재해에 맞춤형으로 제작하는 것이 필요 하다. 이를 위해 실제 발생할 수 있는 위험을 파악하였다. 2020년 통계를 통해 우리나라 산업재해에서 끼임, 넘어짐, 절단·베임·찔림 등의 재해와 감전, 화재, 이상온도접촉, 화 학물질 누출 등의 기타 유형이 큰 비중을 차지하는 것을 확 인할 수 있었다(이현숙, 2020). 이러한 통계자료를 기반으로 작업 중 신체 접근에 의한 사고(끼임, 절단 등), 고온에 의 한 화재 및 화상사고, 누전 및 이상전류에 의한 사고, 및 유 해물질 등 공기질에 의한 작업자 보건문제의 네 가지 산업 재해 유형에 대해서 센서 플랫폼을 개발하고 이를 실증하 고자 하였다.

\section{2. 재해위험 감지 방안}

선정된 주요 문제점이 발생할 수 있는 설비와 이러한 위 험을 인식할 수 있는 센서 및 감지 방안에 대하여 Table 1 과 같이 정리할 수 있다. 작업 중 신체 접근에 의한 사고의 경우 장비 동작 중 위험구역 내에 작업자의 신체나 이상 물 체가 접근하여 발생하는 변화를 비전센서로 감지하도록 하 였다. 누전 및 이상전류에 의한 사고의 경우 본 연구진에서 자체개발한 스마트미터를 활용하여 검출을 진행하였다. 고 온에 의한 화재 및 화상사고의 경우 실제 접촉에 의한 온 도 측정 시 제품 품질에 문제가 발생할 수 있으며 연속적
인 측정에 어려움이 있어 비접촉식 온도센서를 통해 이를 해결하고자 하였다. 마지막으로 화학물질 누출에 의한 작업 자 보건문제의 경우 위험이 예측되는 구역에서 환경감지 센 서를 활용하여 발생이 예상되는 유해가스의 농도를 측정하 였다. 더불어 맞춤형 센서 플랫폼 제작에 있어 센서 및 관 측 방식의 선정뿐 아니라 적절한 알고리즘 적용을 통해 이 러한 위험요소 감지확률을 높이고자 하였다.

또한 위험요소 감지를 통해 실시간으로 작업자 및 관리 자에게 위험 발생상황을 알릴 수 있도록 현장 특성에 맞는 방식을 통해 작업자에게 위험을 알리고, 데이터 처리를 통 해 관리자가 실시간으로 이러한 문제를 파악하여 공장 전 체적으로 해당 문제에 신속하게 대처할 수 있는 것을 목표 로 하였다.

\section{3. 실증 공정선정}

실제적으로 발생할 수 있는 재해위험 감지 시스템의 실 증을 위해 타당성이 높은 공정을 선정하여 개발기술 실증 을 진행하였다. 각각의 공정에서 잠재적으로 발생할 수 있 는 재해위험은 Table 2 와 같이 정리할 수 있다. 각 위험 요 소별로 1 2개 정도의 공정을 선정하여 실제 중소기업에서 실증을 진행하였다. 재해 위험별로 각각 신체 끼임/절단 사 고에 기계가공과 프레스, 과전류/누전에 주조와 기계가공, 고온에 의한 화재 및 화상사고에 압출, 마지막으로 공기질 저하에 주조와 용접 공정을 선정하였다. 최종적으로 발생 가 능한 재해에 맞추어 재해위험 센서 플랫폼을 개발하고 이 를 실증하였다.

\section{재해 종류별 기술개발 및 실증 결과}

\section{1. 작업 중 신체 접근에 의한 사고 방지}

이미지를 기반으로 한 제조현장 안전관련 연구는 비교적 활발하게 수행되고 있으나 대부분 거시적 현장의 상태를 촬 영하여 특정 이상 현상을 인지하는 방법으로 접근하고 있 다(Buerkle et al., 2021). 이러한 방법의 경우 특정 상황에 대 
Table 2. 공정별 잠재적으로 발생 가능한 재해

\begin{tabular}{|c|c|c|c|c|c|}
\hline 재해 위험 & 주조 & 압출 & 기계 가공 & 프레스 & 용접 \\
\hline $\begin{array}{c}\text { 신체 접근에 } \\
\text { 의한 끼임·절단 }\end{array}$ & - & - & $\begin{array}{c}\text { 드릴링/탭핑 장비에 } \\
\text { 신체 부상 }\end{array}$ & $\begin{array}{c}\text { 절곡 공정 중 } \\
\text { 끼임사고 }\end{array}$ & - \\
\hline 과전류/누전 & $\begin{array}{l}\text { 고전류 장비의 } \\
\text { 과전류/누전 }\end{array}$ & $\begin{array}{c}\text { 고전류 장비의 } \\
\text { 과전류/누전 }\end{array}$ & $\begin{array}{l}\text { 수작업 공정 중 } \\
\text { 감전 위험 }\end{array}$ & $\begin{array}{l}\text { 고전류 장비의 } \\
\text { 과전류/누전 }\end{array}$ & $\begin{array}{c}\text { 고전류 장비의 } \\
\text { 과전류/누전 }\end{array}$ \\
\hline $\begin{array}{l}\text { 고온에 의한 } \\
\text { 화재 및 화상 }\end{array}$ & $\begin{array}{c}\text { 고온 주조물로 } \\
\text { 인한 화재 }\end{array}$ & $\begin{array}{l}\text { 고온의 압출물 신체 } \\
\text { 접촉으로 인한 화상 }\end{array}$ & - & - & - \\
\hline $\begin{array}{l}\text { 공기질 } \\
\text { 저하 }\end{array}$ & $\begin{array}{c}\text { 주조물에서 } \\
\text { 유해가스 발생 }\end{array}$ & - & $\begin{array}{c}\text { 가공 중 미세먼지 } \\
\text { 발생 }\end{array}$ & - & $\begin{array}{l}\text { 용접 공정 중 } \\
\text { 유해가스 발생 }\end{array}$ \\
\hline
\end{tabular}

한 인지가 어렵고 넓은 영역에 대해서 연산을 하여야 하기 때문에 연산량이 많아 실시간 위험 탐지를 위해 고성능의 연산장치가 필요하다. 본 연구에서는 산업현장에서 비교적 저렴한 장비로도 활용할 수 있도록 적은 연산량을 갖는 변 화 감지(Change detection) 기법에 기반한 제조 설비 작업 간 위험 특성 인식 및 분석 시스템을 개발하여 적용하였으며 이를 통해 라즈베리 파이(Raspberry Pi)와 같은 저가의 엣지 디바이스로도 이러한 기능을 구현할 수 있었다. 안전설비가 없는 절곡장비에서 실증을 진행하였다. 해당 시스템은 웹캠
을 이용하여 제조 설비의 위험 관심 영역(Region of Interest) 을 촬영하고, 촬영된 이미지의 변화를 분석하여 위험 관심 영역 내에 위험한 변화가 감지되면 이를 경고하는 방법으 로 구성되었다. Figure 1은 드릴링 장비에 해당 알고리즘을 적용시켜 본 것으로 (1) (4)까지 순서대로 다른 이미지, 동일 이미지, 기존 이미지에 화살표를 추가한 이미지 2장이다. 각 각의 목표 이미지와 기준 이미지의 차이를 비교하였을 때 변화된 부분을 감지할 수 있음을 확인하였다.

개발된 안전 모니터링 시스템을 부품 제작업체의 절곡기

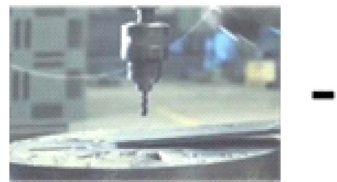

기준 이미제

: 변화영역
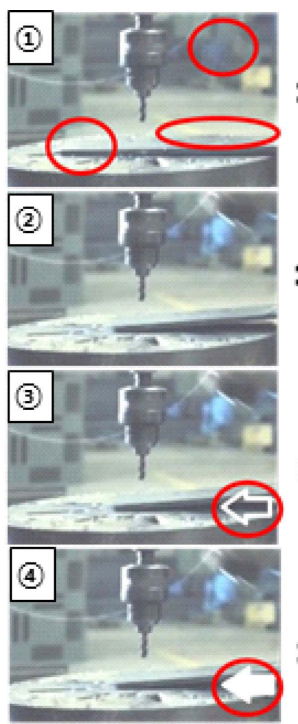

목표 이미지

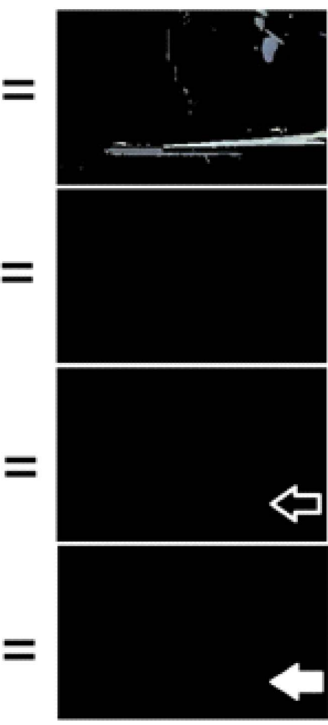

(분석결과

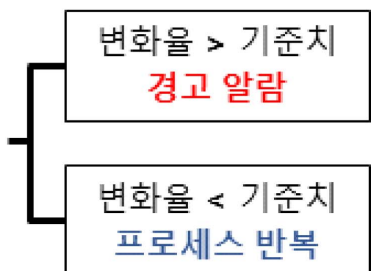

프로세스 반복

Figure 1. 변화 감지 기법을 활용한 위험감지 방안 및 드릴링 공정 적용 예시 

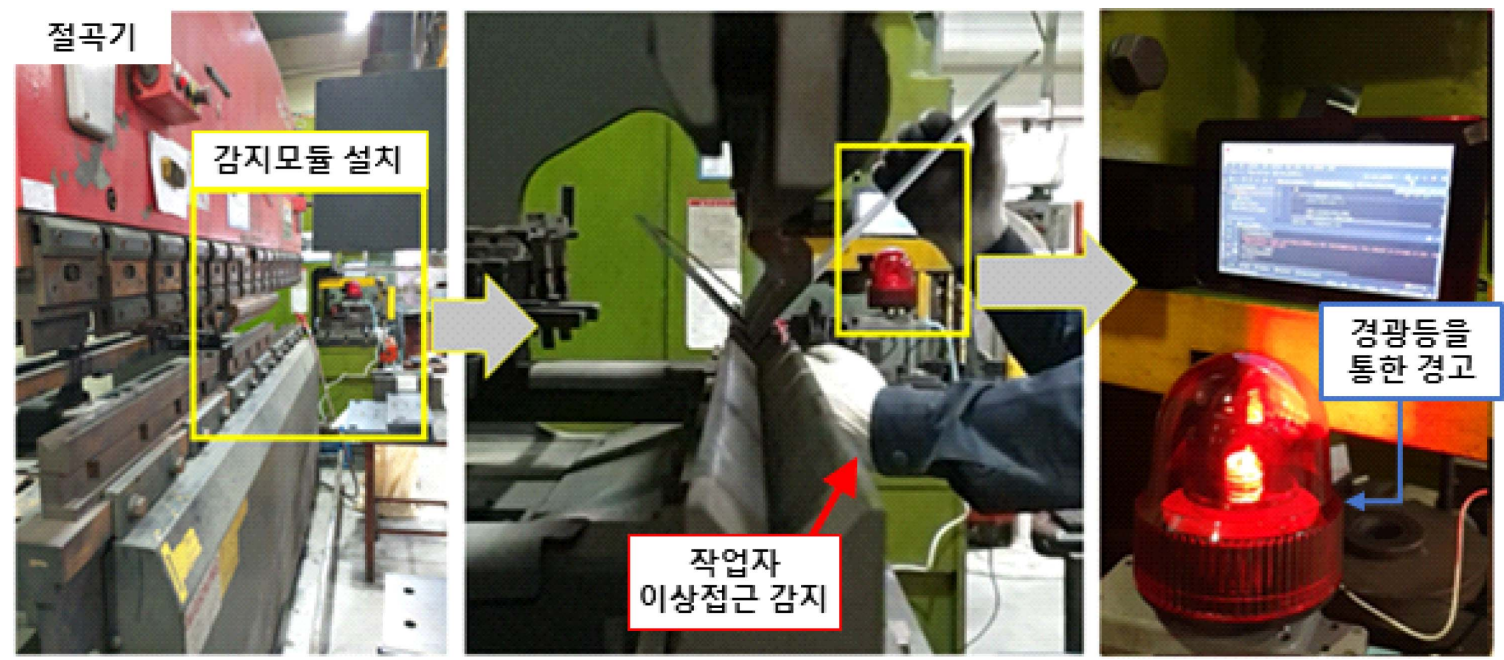

Figure 2. 모니터링 시스템 절곡기 적용 방안 및 작동 프로세스

에 적용하여 실증을 진행하였다(Figure 2). 카메라를 통해 촬 영된 연속적인 작업 이미지를 라즈베리 파이로 구성된 에 지 컴퓨터에 전송하여 처리하며 이미지 처리에 $250 \mathrm{~ms}$ 수 준의 시간이 소요되어 작업자에게 위험한 상황이 발생하였 을 때 이를 대응 가능한 시간 안에 인지함을 확인하였다. 절 곡작업의 경우 작업자가 절곡 장비를 지속적으로 주시하면 서 작업을 진행하기 때문에 경광등과 같은 시각적 경고와 함께 알람부저와 같은 청각적인 자극을 통해 작업자에게 위 험을 알릴 수 있도록 시스템을 구성하였다.

개발된 시스템은 시스템이 판단한 결과와 육안 판단결과 를 비교하여 평가를 진행하였으며, 전체 시험 대비 육안 판 단결과를 기준으로 동일한 결과를 나타내는 경우를 기준으 로 정확도 평가를 진행하였다. 총 120 개의 작업을 수행하는 과정에서 103 개의 작업은 정상, 17 개의 작업은 위험 상황으 로 육안 평가하였는데, 시스템 평가 결과는 정상 103 개 작
업 중 위험으로 인식된 경우가 2회, 위험 17 개 작업 중 정 상으로 인식된 경우가 1 회 발생하였다. 결과적으로 개발된 시스템은 $97.5 \%$ 의 정확도를 갖는 것으로 파악되었다.

\section{2. 누전 및 이상전류}

누전 및 이상전류의 경우 전기를 사용하는 모든 생산현 장에서 발생할 수 있는 문제로 사전 인지를 통한 사고 예 방이 필수적이라 할 수 있다. 특히 높은 전력 소비량을 필 요로 하는 장비나 사람이 직접 작업을 진행하여야 하는 장 비의 경우 누전 사고 발생 시 감전, 장비 파손과 같은 큰 사 고가 발생할 수 있다. 산업현장 배전반에는 기본적으로 배 선 차단기가 설치되어 있어 과전류를 감지하고 빠르게 전 력을 차단하여 이러한 문제를 방지하고 있다. 하지만 보통 하나의 배선에 여러 장비가 연결되기 때문에 그 기준값은 상당히 높게 설정되어 있을 뿐 아니라 장비별 과전류 및 누
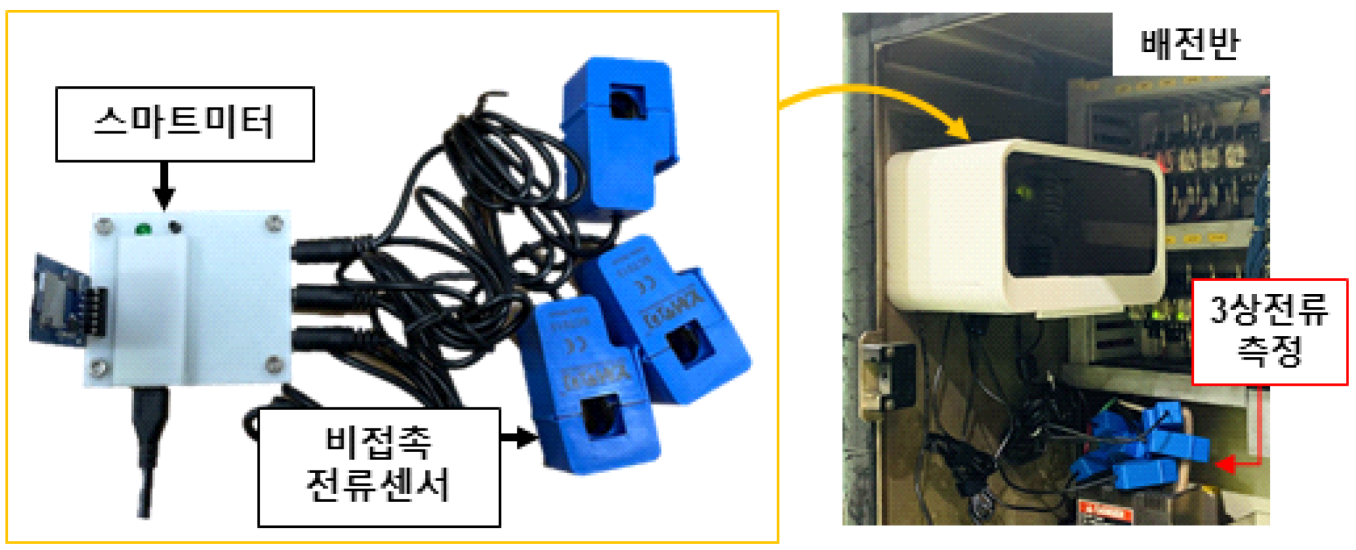

Figure 3. 제작된 전류측정 센서 플랫폼 및 실제 배전반 설치 사례 
전에 대한 관리가 어려우며, 연결된 장비의 케이블 두께에 따라 그보다 더 낮은 전류에서도 화재가 발생할 수 있는 문 제가 있다. 본 연구에서는 이러한 사고를 효과적으로 예방 할 수 있도록 장비별로 전류 프로파일을 측정/분석하여 누 전 및 이상전류 알람을 할 수 있는 센서 플랫폼을 개발하 였으며, 고전류를 필요로 하는 주조장비와 작업자가 직접 작 업을 진행하는 탭핑/드릴링 머신에 대해 실증을 진행하였다.

목표 장비로부터 전력 데이터를 수집하고 제시된 프로토 콜을 통해 서버로 데이터를 전송하기 위해 자체 제작된 스 마트 미터(Smart meter)를 활용하였다(Figure 3). 해당 스마 트미터는 상용 제품에 저가의 부품으로 높은 주파수의 전 류 프로파일을 측정할 수 있어 이상전류/과전류에 대한 검 출이 더 용이한 장점이 있다. 이러한 스마트미터를 활용하 였을 때 전류 데이터를 활용하여 누전위험 뿐 아니라 추후 다양한 정보를 얻을 수 있는 장점이 있으며, 실제 중소기업 에서 사용되는 장비의 전류를 분석하여 생산성, 작업효율 등 다양한 정보를 얻은 연구 사례가 있다(Jung et al., 2020). 교 류 전류의 경우 일정하게 흐르지 않고 특정 값을 기준으로 진동하며 해당 파형은 이상적으로는 정현파의 형태여야 하나 , 실제로는 기기마다 그 진동 양상이 상이하기 때문에 가능 한 빠르게 샘플링하여 RMS(Root-Mean Square)값을 구한 뒤 , 사전 실험을 통해 얻은 관계식을 통해 구간의 평균 전류 를 구하였다. 아두이노 나노(Arduino Nano) 33 IoT를 마이 크로 제어기(Micro controller)로 사용하였으며, 상호작용을 위한 버튼과 발광다이오드를 각각 1 개 포함하고 있다. 스마 트 미터는 업체에서 기존에 사용하던 장비에 아무런 손상 없이 사용 전력량을 계측하기 위해 비접촉 전류센서(SCT$013, \mathrm{YHDC}$ )를 사용하여 측정하였다. 측정한 전류 신호를 스마트 미터에서 읽어 RMS 값을 계산한 후, Wi-Fi를 통해 서버에 설치된 MQTT(Message Queuing Telemetry Transport)
브로커에게 전송한다.

위와 같은 전류측정 센서 플랫폼은 Figure 3 과 같이 실증 을 목표로 하는 각 설비의 배전반에 설치하여 사용전류를 측정하였다. 설치된 플랫폼은 배전반에 설치된 과전류 보호 장치와는 달리 한국전기설비규정에 따라 연결된 케이블에 맞게 과전류 기준값을 설정해줄 수 있으므로(김기현, 2019), 연결된 장비가 바뀌더라도 계속해서 사용할 수 있는 장점 이 있다. 이렇게 측정된 전류 데이터를 실시간으로 작업자 와 관리자가 모두 확인할 수 있도록 모니터링 그래픽 유저 인터페이스(GUI, Graphical User Interface)를 제작하여 시인 성을 확보하였다. 더불어 규정에 따르면 1시간 이상 허용 전 류의 1.45 배의 전류가 흘렀을 때 과부하로 인식하고 보호해 야 한다고 알려야 하기 때문에, 1.2 배의 전류가 누적으로 10 분 이상 발생할 시 “경고” 알림을 주며, 1.45 배의 전류가 누적으로 1시간 발생할 시 “위험” 알림을 모니터링 GUI와

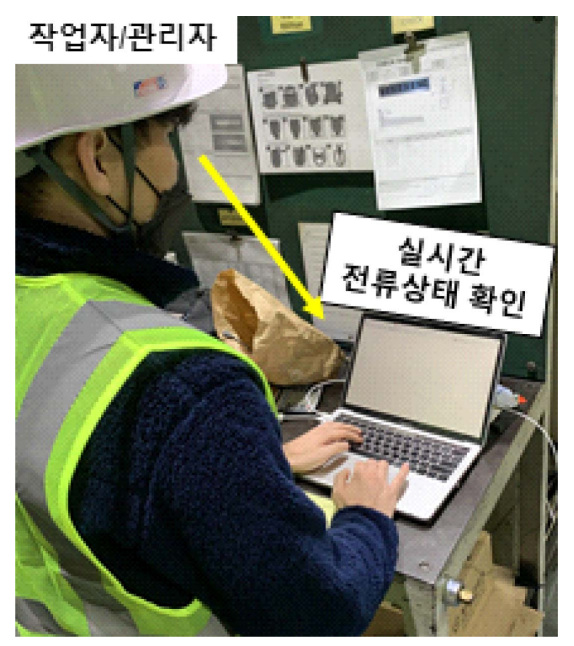

Figure 5. GUI를 통한 작업자-관리자 실시간 전류양상 확인



Figure 4. 전력측정 및 과전류 확인 GUI 
문자로 주도록 하였으며 실시간으로 작업자와 관리자가 다 양한 매체를 통해 확인할 수 있도록 하였다(Figure 4, 5).

과전류 상황은 일반적으로 발생하지 않는 상황이기 때문 에, 이를 검증하기 특정 값 이상의 순간적인 전류를 인식하 는 비율을 확인하여 과전류 인식 성능을 평가하였다. 이를 위해 탭 가공 시 가공 시작/종료 시에 발생하는 순간적인 전 류피크를 과전류로 가정하고 평가를 진행하였다. 피크를 100 번 발생시켰을 때 화면에 “warning”이 뜨는 횟수를 평가 하였고 그 결과 $99 \%$ 의 인식률을 보여 추후 활용이 가능할 것으로 예상된다.

\section{3. 고온에 의한 화재 및 화상}

금속의 압출이나 단조공정과 같이 고온/고압을 필요로 하 는 많은 공정에서 소재의 온도는 생산성과 품질에 큰 영향 을 미치고 있으나 이에 대한 실시간 온도측정을 자동으로 하는 시스템이 필요하다. 하지만 이러한 온도 측정 설비의 추가적인 설치가 어려운 환경에서는 작업자가 작업물의 온 도를 수작업으로 측정하고 있으나, 비효율적이며 작업자의 접근이 필요하다. 특히 알루미늄과 같은 방사율이 낮은 금 속의 생산공정에서 육안이나 피부로 온도를 인식하고 확인 하는 데에는 한계가 있어 화상의 위험이 높은 문제가 있다. 본 연구에서는 알루미늄 압출물과 같은 고온이지만 인식이 어려운 물품의 생산공정에 대해 실시간으로 온도측정을 진 행하고 그 값을 효과적으로 작업자와 관리자에게 알릴 수 있는 방안을 개발하여 실제 알루미늄 압출 업체에 실증하 였다.

알루미늄 압출 공정은 빌렛 가열-압출- 냉각 과정으로 진 행되는데, 각 공정마다 작업물은 끓임없이 움직이고 있으며, 압출 공정 내에서 작업물의 온도는 $50^{\circ} \mathrm{C} \sim 600^{\circ} \mathrm{C}$ 정도로 변 동 폭이 크고, 고온의 환경에서 진행되기 때문에 작업자가 직접 접촉식 온도계로 온도를 확인하는 것은 위험할 뿐 아 니라 측정된 온도도 부정확하다. 이러한 문제들로 접촉식 온 도센서로는 측정할 수 없는 움직이는 물체, 또는 멀리 있는 물체의 온도 측정이 필요한 알루미늄 압출 공정의 경우 비 접촉 온도 모니터링을 진행해야 한다. 비접촉식 온도 센서 의 경우 온도를 바로 반영할 수 있는 빠른 반응속도, 높은 안정성과 같은 제품 자체의 성능 뿐 아니라 작업자의 안전 을 확보할 수 있어 본 연구의 측정환경에 적합하다 할 수 있어 비접촉식 온도 센서를 기반으로 고온 온도 모니터링 모듈을 제작하였다.

모니터링 모듈은 비접촉 온도센서를 구동하기 위한 IoT 부품, 환경센서, 디스플레이, 파워서플라이, 모듈케이스, 다 관절암으로 구성된다(Figure 6). 엣지 컴퓨터를 활용해 비접 촉 온도센서로부터 측정된 데이터를 읽고, 이를 무선으로 통

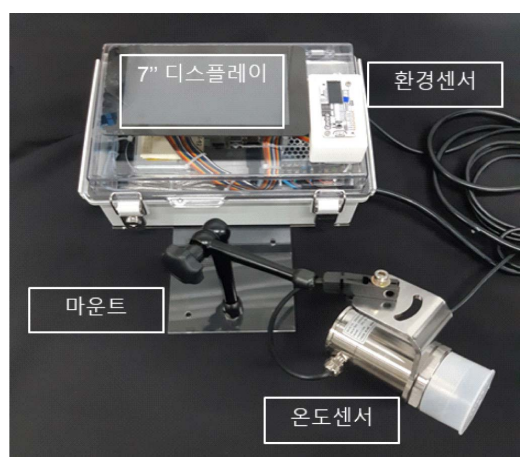

Figure 6. 제작된 온도 모니터링 모듈 (a)

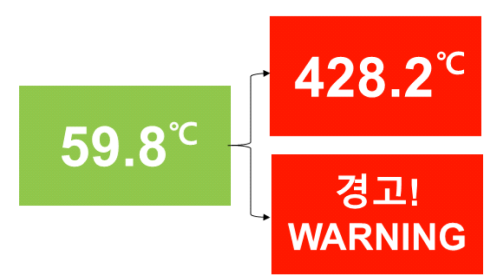

(b)

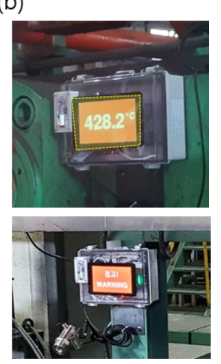

Figure 7. 온도에 따른 경보 표시로 위험요소 시인성 향상 (a) 적 용 이미지, (b) 실제 적용사례

신 가능하여 서버에 업로드 하도록 하였다. 또한 해당 장비 에서 바로 작업자가 온도를 확인할 수 있도록 디스플레이 모듈 배치하였다. 이러한 디스플레이를 활용하여 작업자가 고온 작업물에 대해 현장에서 명확히 인식할 수 있도록 온 도 정보를 보여줌과 동시에, 작업자 안전을 위한 경고 화면 을 표시하도록 하였다(Figure 7).

제작된 온도 모니터링 모듈을 실제 알루미늄 압출 장비, 특 히 제품 품질에 영향을 미치는 주요 위치인 빌렛, 압출 후, 냉각 후 3 개소에 적용하고 온도를 측정하였다(Figure 8). 개 발된 모듈은 실시간으로 온도를 모니터링하여 작업자에게 알려주며 자체 데이터베이스에 실시간으로 온도 데이터를 축적함을 확인하였다. 이후 접촉식 온도계와 비교했을 때, 측정 정확도 $95 \%$ 이상을 보여 실제 활용이 가능한 것으로 판단하였다 $\left(5 \sim 15^{\circ} \mathrm{C}\right.$ 차이 $)$. 또한 주요 3 개소에 온도 모니터 링 모듈과 별도의 대형 대시보드용 디스플레이를 설치하여 작업자로 하여금 작업물 온도에 대한 가시성을 향상시켰다.

더불어 작업자의 작업 동선 내 10 개 지점에서 작업자가 작업중인 위치에서 가까운 지점의 온도를 직접 확인할 수 있는지를 평가를 진행하였다(빌렛 가열부, 압출부, 냉각부 3 개 지점). 평가 기준에 따라 작업자가 작업물의 온도를 확 인할 수 있는지를 평가하였다. 작업자 위치에서 가까운 작 업물 온도는 모두 확인할 수 있음을 확인하였으며, 더불어 




Figure 8. 주요 위치별온도 측정 모듈 및 대시보드 설치를 통한 온도 가시성 향상

10 개 지점 중 냉각부에 부근 1-3번 위치를 제외한 모든 지 점에서 대형 디스플레이를 통해서도 모니터링 가능한 모든 온도를 확인 가능한 것을 확인하였다.

\section{4. 공기 중 유해물질}

실내환경에서 작업이 진행되는 대부분의 작업환경에서 공기질에 의한 위험요소가 존재한다. 특히 열 기반 공정을 진행하는 경우 활용하고있는 소재 자체, 혹은 주변 공기와 의 반응으로 인해 오염물질이 배출될 수 있으며 이는 작업 자 건강에 큰 위험요소가 된다. 본 연구에서는 고온의 열을 필요로 하는 알루미늄 주조 공정과 용접 공정에서 발생할 수 있는 질소산화물 $\left(\mathrm{NO}_{\mathrm{x}}\right)$ 과 오존 $\left(\mathrm{O}_{3}\right)$ 을 검출할 수 있는 플 랫폼을 각각 제작하고 이를 실증하였다.

\section{1. 주조 공정에서 질소산화물 농도 측정}

질소산화물은 연료를 태울 때 배출되는 대기오염 물질로 주로 이산화질소 $\left(\mathrm{NO}_{2}\right)$ 형태 배출되며, 특히 알루미늄 주조 공정에서는 알루미늄 용해과정 중 질소산화물, 일산화탄소, 탄산가스 등 인체에 유해한 오염 물질이 배출된다. 따라서 알루미늄 주조 현장에서 작업자의 안전을 확보하기 위한 실 시간 공기질 상태를 모니터링하는 시스템이 필수적이라 할 수 있으며, 특히 질소산화물은 인체에 치명적인 영향을 미 칠 수 있는 유해가스로서 작업환경에서의 위험을 선제적으 로 경고할 필요가 있다.

본 과제에서 적용한 $\mathrm{NO}_{\mathrm{x}}$ 가스센서모듈은 자체 개발한 구 조색 기반 $\mathrm{NO}_{\mathrm{x}}$ 가스 측정 센서(Kim et al., 2021)와 상용 $\mathrm{NO}_{\mathrm{x}}$ 센서를 결합한 센서이며, 이는 작업환경의 $\mathrm{NO}_{\mathrm{x}}$ 농도를 수 치로 측정 및 전송할 수 있을 뿐만 아니라 센서 자체의 색 변화를 통해 시각적으로 $\mathrm{NO}_{\mathrm{x}}$ 가스의 노출 상태를 확인할 수 있다. 이러한 가스 센서모듈은 저전력 센서(PPG 센서)를 활 용해 오랜 기간동안 휴대용으로 활용할 수 있으며, 간단한

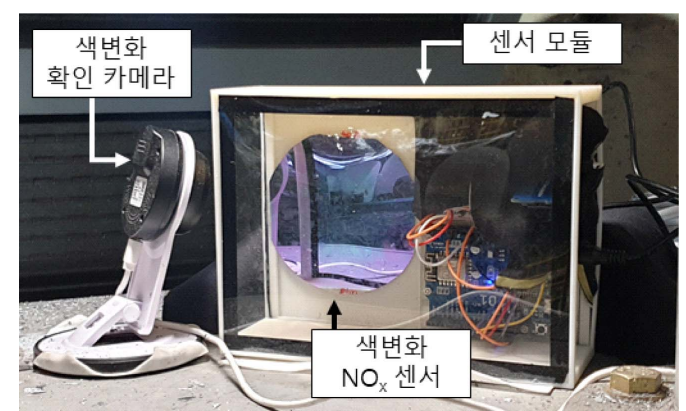

Figure 9. NOx 가스센서 모듈 및 실제 설치양상

공정으로 생산될 수 있어 가격이 저렴한 장점이 있다. 개발 된 플랫폼에는 $\mathrm{NO}_{\mathrm{x}}$ 가스를 실시간으로 측정하는 복합센서 뿐 아니라 실제 고농도의 $\mathrm{NO}_{\mathrm{x}}$ 가 감지되었을 때 이를 시각 적으로 확인하기 어려운 관리자도 확인할 수 있도록 색변 화 확인 카메라를 함께 구성하였다(Figure 9). 유해가스 센 서의 인식률을 검증하기 위해 실험실 환경에서 개발된 시 스템으로 센서 인식률 분석 진행. 실제 인체에 유해한 농도 기준인 1 5 ppm 농도의 유해가스 환경에서 실험을 진행하 였으며 실험 결과 $\mathrm{NO}_{\mathrm{x}}$ 가스 센서가 $90 \%$ 이상의 인식률을 가짐을 확인하였다.

개발된 센서와 경광등을 실제 알루미늄 주조 크루시블 주 변에 설치하여 위험 수준의 유해가스 발생 시 작업자들에 게 위험을 알리도록 하였으며, 해당 센서의 데이터는 1 분 간 격으로 데이터를 클라우드 서버에 저장하며 이를 통해 작 업자 뿐만 아니라 관리자도 실시간으로 작업현장의 $\mathrm{NO}_{\mathrm{x}}$ 유 해가스의 노출 상황을 모니터링 할 수 있도록 하였다.

\section{2. 용접공정에서 오존 발생수준 측정}

제조 현장은 절삭, 용접, 화학처리 등 다양한 제조 공정 이 수행되는 과정에서 많은 유해 물질이 발생하는데, 특히 
용접 작업장에서는 일산화탄소, 오존, 탄산가스, 불화수소 등의 유해가스가 발생하게 된다. 특히 오존가스의 경우에는 짧은 시간의 노출에도 신체에 치명적인 영향을 미칠 수 있 으므로 실시간으로 모니터링하고 선제적으로 경고를 제공 할 필요가 있다. 본 연구에서는 이러한 오존가스 발생 수준 을 질소산화물 측정시와 마찬가지로 실시간으로 측정, 데이 터 전송 및 경고 알림을 진행할 수 있는 오존농도 측정 플 랫폼을 제작하고, 이를 통해 작업자와 관리자 모두에게 위 험상황을 인지할 수 있도록 하였다.

오존센서 플랫폼은 상용적으로 많이 활용되는 장비를 활 용하여 추후 공장에서도 비용이나 기술적인 난이도에 부담 을 적게 느끼면서 활용할 수 있도록 하였다. 적용된 오존 센 서(MQ-131, SZH)는 오존가스과 같이 산화물에 높은 감도 를 보유한 직독 방식 센서로 저농도 및 단기간 노출 측정 에 유용한 센서이다. 시스템은 오존 센서와 소형 및 저가형 마이크로 컴퓨팅 장치인 아두이노/라즈베리 파이(Raspberry $\mathrm{Pi}$ 를 활용하여 구성하였으며, 경고장치로는 경광등과 경고 음이 동시에 발생하는 회전경광등을 적용하여 작업자가 거 리 및 작업방향에 관계없이 위험을 인지할 수 있도록 하였다. 개발된 오존센서 기반 제조현장 공기질 모니터링 시스템 의 실증을 위해 용접로봇 작업 공간에 총 4 대의 오존센서 기반 모니터링 시스템을 설치하고 운영하였다(Figure 10). 센서가 설치된 제조현장의 오존 농도가 안전수치를 초과할 경우 현장 작업자들에게 즉시적 경고를 제공하여 오존 과 농도 지역 이탈 및 환기 등의 조치를 취할 수 있었다. 개발 된 오존 모니터링 시스템은 산업안전보건법에 명시된 이온 크로마토그래피(Ion Chromatography, IC) 분석 방식으로 공 기중 오존량을 분석하는 방법과 비교를 통해 측정 정확도 를 평가를 진행하였다. 직독식 방식과 IC 방식의 측정방식 차이로 일부 수치 차이를 보이기는 하였으나, 모든 측정방 식 결과에서 작업장 내 기준을 초과하는 오존 농도 수치가 발생함을 확인하였다. 측정은 용접 로봇이 없는 복도와 용 접로봇 2 대에서 진행하였으며 각각 1 시간씩 총 3 회 측정하 여 결과를 비교하였다. 총 9 번의 측정 중 IC 측정기법을 통 해 오존농도 기준치 초과된 3 번의 측정에 대해 모두 기준 치 $(0.08 \mathrm{ppm})$ 를 초과하는 측정값을 측정함을 확인하였으며 이를 통해 개발된 시스템을 이용하여 제조현장의 오존을 효
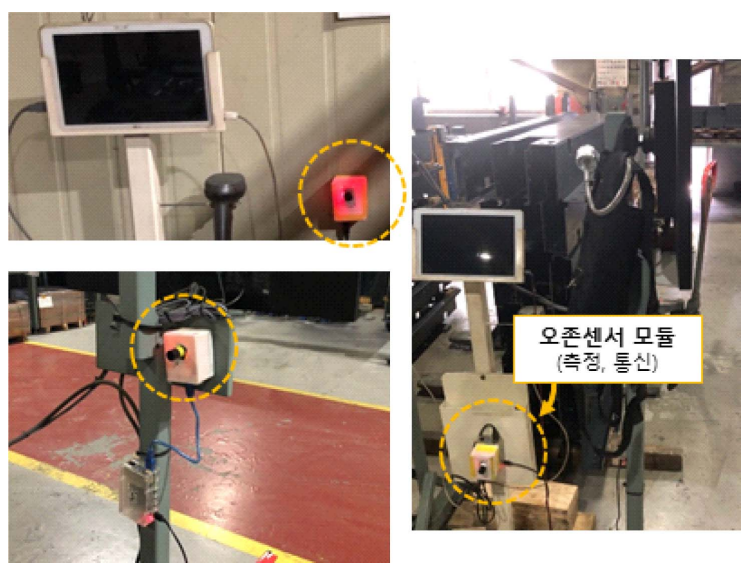

Figure 10. 오존센서 기반 모니터링 시스템 설치

과적으로 측정할 수 있을 것으로 판단할 수 있었다.

\section{결론 및 제언}

본 연구를 통해 중소기업에서 활용 가능한 적정 스마트 공장 기술을 활용하여 실제 산업현장에서 적용 가능한 맞 춤형 데이터 수집 및 모니터링 기술을 개발하고 작업자 및 관리자가 안전관련 이슈를 관리할 수 있도록 알림방안을 적 용하여 이를 실증하였다. 개발된 기술을 적용하였을 때의 위 해 인식 결과는 Table 3에 정리하였다. 이를 통해 산업재해 중 많은 비중을 차지하는 신체 접근에 의한 사고, 고온에 의 한 화재 및 화상사고, 누전 및 이상전류에 의한 사고와 유 해물질 등 공기질에 의한 작업자 보건문제에 대해 위험요 소를 감지 및 경고할 수 있는 센서 플랫폼을 개발하였으며 이를 주조, 압출, 기계가공, 프레스 및 용접 공정에 실증하 여, 적정 스마트공장 기술이 실제로 안전관련 데이터 모니 터링 및 분석 뿐 아니라 공장 안전환경 개선에도 도움이 될 수 있음을 확인하였다. 추후 연구를 통해 더 많은 산업재해 종류에 대해 맞춤형 기술을 개발할 수 있을 것으로 예상되 며, 각 맞춤형 기술의 조합을 통해 다양한 업종의 업체에 적 정 스마트공장 기술을 통한 안전개선을 진행할 수 있을 것 으로 기대된다.

Table 3. 안전 세이프공장 구축을 위한 센서 모듈 적용결과

\begin{tabular}{|c|c|c|}
\hline 목표 & 인식 방안 & 성과 \\
\hline 신체 접근에 의한 사고방지 & 비전 센서 & 위해 인식률 $97.5 \%$ \\
\hline 온도 측정을 통한 손상 위험인식 & 비접촉 온도센서 & 작업물 온도 인식률 $99 \%$ \\
\hline 과전류 인식 & 비접촉 전류센서 & 과전류 인식 정확도 $95 \%$ 이상 \\
\hline 공기질 유해성 인식 & 가스 농도센서 & 유해성 인식 $90 \%$ 이상 \\
\hline
\end{tabular}




\section{사사}

이 성과는 경기도와 경기산학융합원의 지원을 받아 수행 되었으며(시화반월산단 산학융합지구 성과활용 지원사업), 시화공단의 (주)동광사우와 (주)알루원의 협조에 감사드립니다.

\section{References}

Afrin, M., Jin, J., Rahman, A., Tian, Y. C., and Kulkarni, A. (2019). Multi-objective resource allocation for edge cloud based robotic workflow in smart factory. Future Generation Computer Systems, 97, pp. 119-130.

Buerkle, A., Eaton, W., Lohse, N., Bamber, T., and Ferreira, P. (2021). EEG based arm movement intention recognition towards enhanced safety in symbiotic Human-Robot Collaboration, 70, Robotics and Computer-Integrated Manufacturing, 102137.

Cheng, Z., Likai, J., Min, C., and Xiangyan, Z. (2021). Mechanical Safety Risk Analysis of Smart Factory. Journal of Physics: Conference Series, 1884(1), pp. 012037.

Jeong, P. S., and Cho, Y. H. (2019). Smart Factory Safety Management System using Bluetooth, Journal of the Korea Convergence Society, 10(11), pp. 47-53.

Jung, W. K., Kim, D. R., Lee, H., Lee, T. H., Yang, I., Youn, B. D., Daniel Zontar, Matthias Brockmann, Christian Brehcer, and Ahn, S.H. (2021). Appropriate Smart Factory for SMEs: Concept, Applic anation and Perspective, International Journal of Precision Engineering and Manufacturing, 22, pp. 201-215.

Jung, W. K., Kim, H., Park, Y. C., Lee, J. W., and Ahn, S. H. (2020), Smart sewing work measurement system using IoTbased power monitoring device and approximation algorithm,
International Journal of Production Research, 58(20), pp. 6202-6216.

Kim, Y. G., Quan, Y. J., Kim, M. S., Cho, Y. G., and Ahn, S. H. (2021), Lithography Free and Highly Angle Sensitive Structural Coloration using Fabry-Perot of Tin, International Journal of Precision Engineering and Manufacturing-Green Technology, 8(3), pp. 997-1006.

Lee, T., Kim, Y., and Jung, H. (2021), Dataset Construction and Model Learning for Manufacturing Worker Safety Management, Journal of the Korea Institute of Information and Communication Engineering, 25(7), pp. 890-895.

김기현. (2019). 한국전기설비규정(KEC)에 따른 감전 및 과전 류 보호 규정 및 설계 방법, 한국조명전기설비학회지, 33(6), pp. 3-12.

산업통상자원부, 한국생산기술연구원, 국가뿌리산업진흥센터. (2020). 2020년 뿌리산업 실태조사, pp. 104.

안성훈. (2018). '적정 스마트 팩토리'로 中企 생산성 높여야, 한국경제, https://www.hankyung.com/opinion/article/ 2018092111451 (accessed Nov. 2021).

오병선. (2021). 산업보건 어제와 오늘-「중대재해처벌법」의 내용과 기업의 대응, 산업보건, 8월호, pp. 42-49.

이현숙. (2020), 2020. 12월말 산업재해 발생현황, 고용노동부, pp. 5-11.

장현주. (2018). 안성훈 中쇼에 맞는 低비용·최적효율 스마트팩 토리 개발, 한국경제, https://www.hankyung.com/society/ article/2018101430321 (accessed Oct. 2021).

중소기업중앙회. (2021). 「중대재해처벌법 이행준비 및 애로사 항」기업 실태조사 결과, pp. 2.

중소기업기술정보진흥원. (2017). 스마트공장 추진과정의 애로 사항. https://kosis.kr/statHtml/statHtml.do?orgId=398\&tblId =DT_398001N_2016_N044. (accessed Nov. 2021). 